\title{
GENETIC CHARACTERIZATION OF TWO POPULATIONS OF BONNEVILLE CUTTHROAT TROUT IN GREAT BASIN NATIONAL PARK, USA
}

\author{
Derek D. Houston ${ }^{1}$, R. Paul Evans ${ }^{2}$, Jared M. Crowley ${ }^{3}$, and Dennis K. Shiozawa ${ }^{3}$
}

\begin{abstract}
The cutthroat trout (Oncorhynchus clarkii) is a popular sport fish that is native to the waters of western North America. Cutthroat trout comprises many subspecies, each of which has experienced range reduction resulting from anthropogenic activities. Hence, there is a general interest from management agencies to assess the genetic structure of managed populations of cutthroat trout subspecies to ensure that proper conservation plans are implemented. Herein, we utilize microsatellite data to characterize the genetic composition of 2 populations of Bonneville cutthroat trout in Great Basin National Park: Mill Creek and South Fork Big Wash. Mill Creek was used as a source population for reintroduction into South Fork Big Wash in the year 2000, and there is concern that South Fork Big Wash may have experienced a population bottleneck after, or during, the stocking effort. We found that both populations exhibit low genetic diversity, and that the source population, Mill Creek, exhibited mixed signals of having undergone a recent population bottleneck. Structure analysis revealed 4 distinct groups, but those groups did not segregate geographically, although a significant pairwise $\mathrm{F}_{\mathrm{ST}}(0.06727, P<0.00001)$ between Mill Creek and South Fork Big Wash populations suggests that some genetic differentiation has occurred.
\end{abstract}

RESUMEN.-La trucha (Oncorhynchus clarkii) es un pez popular en la pesca deportiva, nativo de las aguas del oeste de América del Norte. Esta trucha comprende muchas subespecies, cada una de las cuales ha experimentado reducciones en su rango de distribución resultantes de las actividades antropogénicas. Por lo tanto, existe un interés general de los organismos de gestión para evaluar la estructura genética de las poblaciones gestionadas de subespecies de trucha para asegurar que los planes de conservación sean aplicados adecuadamente. Utilizamos datos de microsatélites para caracterizar la composición genética de dos poblaciones de trucha en Bonneville en el Parque Nacional Great Basin, Mill Creek y South Fork Big Wash. La población de Mill Creek fue utilizada como una fuente para la reintroducción en South Fork Big Wash en el año 2000, y existe la preocupación de que South Fork Big Wash pudo haber experimentado un cuello de botella después, o durante el esfuerzo de reintroducción. Encontramos que ambas poblaciones tienen baja diversidad genética, y que la población de Mill Creek, presentan señales mixtas de haber pasado por un reciente evento de cuello de botella. El análisis de estructura poblacional reveló cuatro grupos distintos, pero esos grupos no segregaron geográficamente, aunque hay un $\mathrm{F}_{\mathrm{ST}}$ significativo $(0.06727, P<0.00001)$ entre las poblaciones de Mill Creek y de South Fork Big Wash sugiere que se ha producido una diferenciación genética.

The identification of conservation units (i.e., evolutionary significant units, management units, etc.) within a species is critical to maintaining genetic diversity, an important management objective (Waples 1994, Moritz 1999, 2002, Wang et al. 2002, Reed and Frankham 2003). An essential step in this process is the collection of data that can be used to identify genetically distinct populations (e.g., Peterman et al. 2013). Preserving these populations helps maintain total genetic diversity, which gives species the ability to persist over time (O’Brien et al. 1985, Allendorf and Leary 1988, Spielman et al. 2004). The loss of genetic diversity within a species increases extinction risk by causing a decreased ability to adapt to environmental change and a reduction in fitness due to inbreeding depression (Newman and Pilson 1997, Amos and Balmford 2001, Charlesworth and Willis 2009). In addition to contributing to total genetic diversity, genetically distinct populations can also be important to the evolutionary legacy of a species. Populations at the periphery of a species' range are often genetically distinct, and can be where the first steps in speciation occur (Lesica and Allendorf 1995, Dennenmoser et al. 2013). Conserving genetically unique populations therefore decreases the likelihood of extinction and simultaneously allows for the continued evolution of the species.

Reduced genetic variation is of general concern in small, isolated populations (Ellstrand and Elam 1993, Lacy 2000), or in populations

\footnotetext{
${ }^{1}$ Department of Ecology, Evolution, \& Organismal Biology, Iowa State University, 251 Bessey Hall, Ames, IA 50011. E-mail: derek.d.houston@gmail.com ${ }^{2}$ Department of Microbiology and Molecular Biology, Brigham Young University, 4007 LSB, Provo, UT 84602.

${ }^{3}$ Department of Biology, Brigham Young University, 4101 LSB, Provo, UT 84602.
} 
that have experienced founder effects. A reduction in genetic variation can be accompanied by inbreeding and the fixation of deleterious traits (Hedrick and Kalinowski 2000). Such traits can be manifest through fluctuating asymmetry (Leary et al. 1985), reduced fecundity (Kincaid 1976, Su et al. 1996), reduced survivorship, and so forth. In such cases, it can be useful to introduce additional genetic diversity from outside sources to prevent genetic load associated with inbreeding depression. Therefore, it is worthwhile to periodically evaluate conservation populations to ensure that the proper conservation plan is implemented.

The most widely distributed native trout in western North America is the cutthroat trout, Oncorhynchus clarkii. The species comprises 10 extant and 2 extinct subspecies, and 3 of the extant cutthroat trout subspecies are threatened (see Houston et al. 2012). Extensive analysis of population genetic structure is limited to studies on just a few subspecies, mainly coastal, westslope, Lahontan, and Yellowstone cutthroat trout (Wenburg et al. 1998, Nielsen and Sage 2002, Taylor et al. 2003, Young et al. 2004, Cegelski et al. 2006, Robinson et al. 2009, Vu and Kalinowski 2009). All subspecies, however, have undergone a drastic reduction in geographical distribution due primarily to the introduction of nonnative fishes and habitat modification (Allendorf and Leary 1988, Behnke 2002, Trotter 2008, Metcalf et al. 2012, Yau and Taylor 2013).

The Bonneville cutthroat trout, Oncorhynchus clarkii utah, is native to drainages within the Bonneville Basin and was interconnected through tributaries to pluvial Lake Bonneville. Bonneville cutthroat trout populations were fragmented with the desiccation of Lake Bonneville at the end of the Pleistocene Epoch. More recently, many native trout habitats have also been altered by anthropogenic activities including irrigation, grazing of livestock, introduction of nonnative fishes, and changing global climate.

Great Basin National Park is located on the western edge of the Bonneville Basin, the periphery of the range of the Bonneville cutthroat trout. Fourteen conservation populations of Bonneville cutthroat trout occur in Great Basin National Park and the surrounding Mount Moriah Wilderness Area (Snake Range, NV). Two of these populations, South Fork Big Wash and Mill Creek (Fig. 1, Table 1), both in
Great Basin National Park, are of particular interest to Great Basin National Park, which oversees the management of these populations. When surveyed by National Park Service and Nevada Department of Wildlife officials in 1999, South Fork Big Wash was unpopulated by cutthroat trout but was restored beginning in the year 2000, using Mill Creek cutthroat trout as a source population. The transfer of fish into the South Fork Big Wash Creek occurred over 2 years, one transfer in July 2000 and the other in July 2001. These populations have not had any additional transfers, nor have they been evaluated genetically since then, but concern exists that the South Fork Big Wash population may have experienced a reduction in genetic diversity resulting from a founder effect with the original stocking effort.

Our objectives were to compare genetic variation within the South Fork Big Wash population, restored in the year 2000, to that of the source population, Mill Creek, and to assess the genetic composition of each stream. We used microsatellite markers to assess the genetic status of 68 individual cutthroat trout samples from these 2 populations to determine whether any signature of a population bottleneck is evident.

We anticipated several possibilities. First, if substantial microsatellite variability exists in the source population, then the restored population should contain at least a subset of this variation. It is unlikely that the entire diversity of the source population (Mill Creek) would have been transferred to the new population (South Fork Big Wash). However, the source population may have also undergone significant bottleneck effects following the desiccation of Lake Bonneville, or as a result of more recent anthropogenic habitat manipulations. Thus, it is possible that genetic diversity of the parent population is also very low. It is also possible that either population (or both) has experienced postrestoration bottlenecks.

\section{Methods}

\section{Sampling and DNA Isolation}

The National Park Service and the Nevada Division of Wildlife provided fin clips of 68 Bonneville cutthroat trout individuals collected in 2010 for genetic analysis: 34 from South 


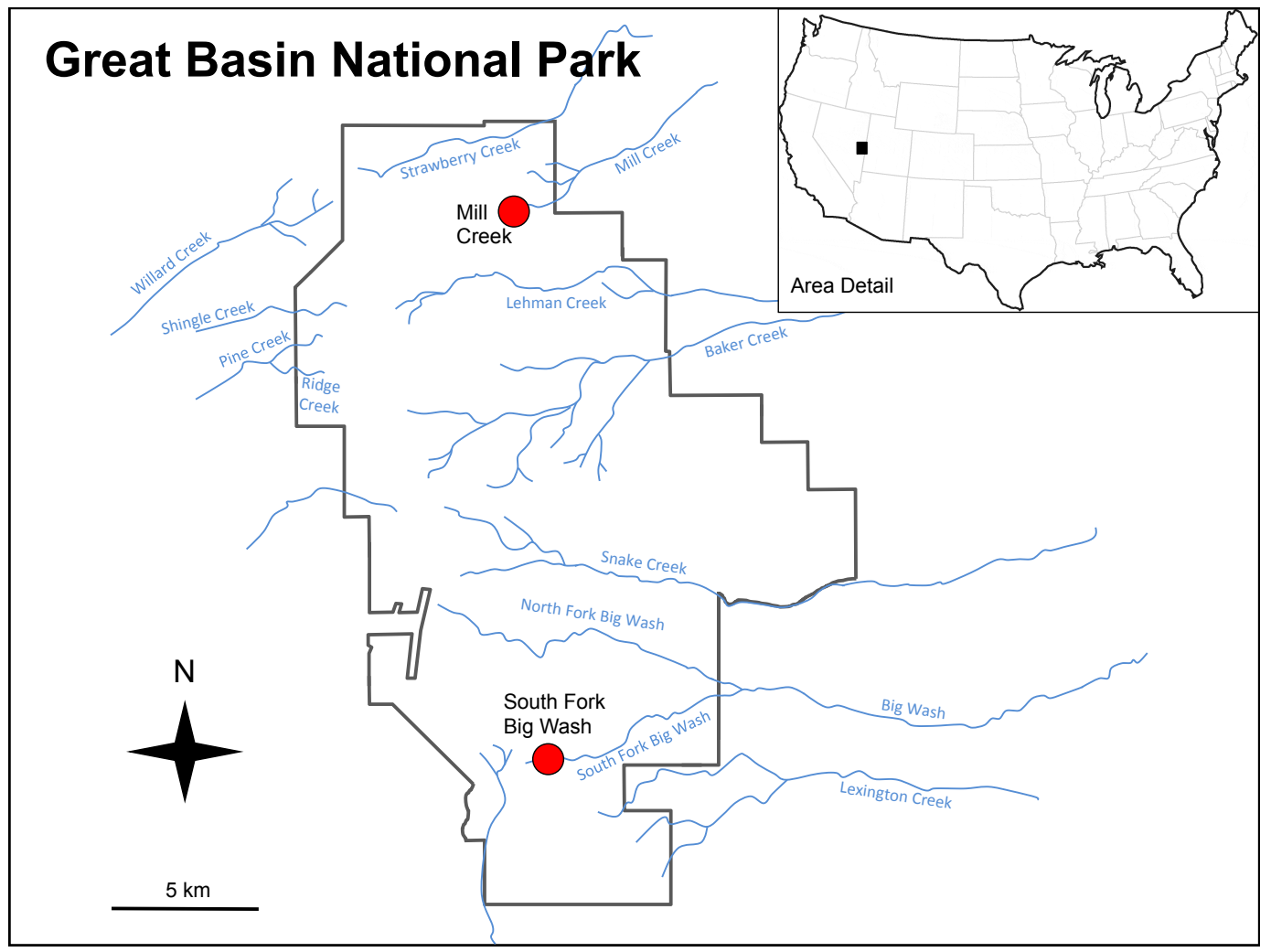

Fig. 1 Map of Great Basin National Park showing the locations of Mill Creek and South Fork Big Wash where Bonneville cutthroat trout were sampled

TABLE 1. Locality information for populations of cutthroat trout in Great Basin National Park for which microsatellite data were generated for this study.

\begin{tabular}{llccc}
\hline Location & Latitude, longitude & $n$ & $\begin{array}{c}\text { BYU } \\
\text { population number }\end{array}$ & $\begin{array}{c}\text { BYU } \\
\text { identification number }\end{array}$ \\
\hline Mill Creek & $39.041^{\circ} \mathrm{N}, 114.253^{\circ} \mathrm{W}$ & 34 & 7335 & $181978-182011$ \\
South Fork Big Wash & $38.874^{\circ} \mathrm{N}, 114.222^{\circ} \mathrm{W}$ & 34 & 7334 & $181945-181977$ \\
\hline
\end{tabular}

Fork Big Wash and 34 from Mill Creek (Table 1). We extracted whole genomic DNA from fin clips using Qiagen DNeasy tissue kits according to the manufacturer's recommended protocols. Unused tissues have been catalogued and stored in the Monte L. Bean Life Science Museum ichthyological collection at Brigham Young University (BYU). The DNA extracts were stored at $4{ }^{\circ} \mathrm{C}$ during the analysis, and have been placed at $-80{ }^{\circ} \mathrm{C}$ for long-term storage.

Polymerase Chain Reaction and Genotyping

Microsatellite regions were amplified via the polymerase chain reaction (PCR) using a 3-primer system that incorporated a fluorescently labeled M13 primer rather than a fluorescently labeled forward primer in each microsatellite primer pair (Schuelke 2000, Blacket et al. 2012). The $5^{\prime}$ end of each microsatellite forward primer was expanded to include an M13 forward sequence (CAC GAC GTT GTA AAA CGA C; Hanna et al. 2012). The extended forward primer was then used in conjunction with an M13 primer that was fluorescently labeled with either 6-FAM or HEX. Hence, each PCR cocktail contained 3 primers: a 5 '-augmented microsatellite forward primer, a fluorescently labeled M13 
forward primer, and an unmodified microsatellite reverse primer. Microsatellite primers are listed in Table 2. Reactions were $12.5 \mu \mathrm{L}$ in total volume and contained the following ingredients: $2.3 \mu \mathrm{L}$ molecular grade $\mathrm{H}_{2} \mathrm{O}$, $0.05 \mu \mathrm{L} 5^{\prime}$-augmented microsatellite forward primer, $0.45 \mu \mathrm{L}$ fluorescently labeled M13 forward primer, $0.45 \mu \mathrm{L}$ unmodified reverse primer, $6.25 \mu \mathrm{L}$ of Promega GoTaq master mix, and $3 \mu \mathrm{L}$ of DNA. The thermal profile consisted of an initial denature at $95{ }^{\circ} \mathrm{C}$ for 2 min, followed by 40 cycles of $95{ }^{\circ} \mathrm{C}$ for $15 \mathrm{~s}$, primer specific annealing temperature (ranging from $50{ }^{\circ} \mathrm{C}$ to $60{ }^{\circ} \mathrm{C}$, see Table 2) for $90 \mathrm{~s}$, and extension at $72{ }^{\circ} \mathrm{C}$ for $90 \mathrm{~s}$; a final extension at $72{ }^{\circ} \mathrm{C}$ for $10 \mathrm{~min}$ ran at the conclusion of the last cycle and that was followed by a $4{ }^{\circ} \mathrm{C}$ hold.

Successful PCR amplifications of the microsatellite loci were verified qualitatively by viewing bands following gel electrophoresis. PCR products were diluted 1:50 with nuclease-free water, then $10 \mu \mathrm{L}$ of each diluted sample was added to the appropriate well of a new 96-well plate and dried prior to genotyping. Samples were genotyped on an ABI 3100 automated sequencer after $0.3 \mu \mathrm{L}$ of ROX 500 size standard and $12 \mu \mathrm{L}$ HiDi Formamide were added to each dried sample. Peaks were initially scored automatically using PEAKSCANNER (Applied Biosystems), and final scoring of microsatellite alleles was performed by eye using the software program GENEIOUS v.6.1.4 (Biomatters; www.geneious .com).

\section{Population Genetic Analyses}

We used MICRO-CHECKER v.2.3.4 (Van Oosterhout et al. 2004) to check for possible genotyping errors (i.e., stuttering, large allele dropout, and null alleles). We used ARLEQUIN v.3.5.1.3 (Excoffier and Lischer 2010) to calculate the number of alleles, the size range of alleles, the expected and observed heterozygosities (needed to perform HardyWeinberg equilibrium tests), and a pairwise $\mathrm{F}_{\mathrm{ST}}$ estimate between the 2 cutthroat trout populations. The input files for ARLEQUIN were created using the file conversion option in GENEPOP v.4.2 (Raymond and Rousset 1995, Rousset 2008).

We used BOTTLENECK v.1.2.02 to determine whether populations had undergone genetic bottlenecks (Cornuet and Luikart
1996). The null hypothesis is that the populations are in mutation-drift equilibrium (i.e., there is no signature of a recent population bottleneck). However, we infer that populations exhibiting significant heterozygosity excesses have experienced a recent bottleneck (Cornuet and Luikart 1996). Such a signal results from a Hardy-Weinberg imbalance following a recent bottleneck and dissipates over time as generations of random mating return the population to equilibrium, albeit with reduced genetic variation. We performed sign tests, standardized differences tests, and Wilcoxon rank tests in BOTTLENECK under the infinite alleles model and the stepwise mutational model based on 1000 iterations.

We used STRUCTURE (Pritchard et al. 2000) and STRUCTURE-HARVESTER (Earl and vonHoldt 2012) to assess whether the Mill Creek and South Fork Big Wash populations were genetically distinct. The STRUCTURE analysis was evaluated 30 times for each $\mathrm{K}$ (with $\mathrm{K}$ ranging from 1 to 8), with $1,000,000$ repetitions per run after discarding the first 100,000 repetitions as burn-in.

\section{REsults}

\section{Polymerase Chain Reaction and Genotyping}

Thirteen primer sets successfully amplified microsatellite loci in Bonneville cutthroat trout samples from South Fork Big Wash and Mill Creek. One locus that did amplify reliably, Fgt3, was not possible to score because of multiple peaks from pronounced stuttering; thus it was excluded from further analyses. The other 12 microsatellite loci showed no evidence of genotyping errors resulting from stuttering, null alleles, or large allele dropouts.

Twelve microsatellite loci showed varying levels of allelic diversity in the Mill Creek and South Fork Big Wash Bonneville cutthroat trout populations (Table 3). Some loci were monomorphic despite being variable in test runs on other Bonneville cutthroat trout populations (DDH unpublished data). The Mill Creek samples contained 4 monomorphic loci (H118, J14, J132, Oc18), and the South Fork Big Wash samples contained 3 monomorphic loci (H118, J14, J132). The number of alleles per locus in each population ranged from 1 to 9 (Table 3). The aforementioned monomorphic loci accounted for the low end of that range, and the loci with the highest amount of allelic 


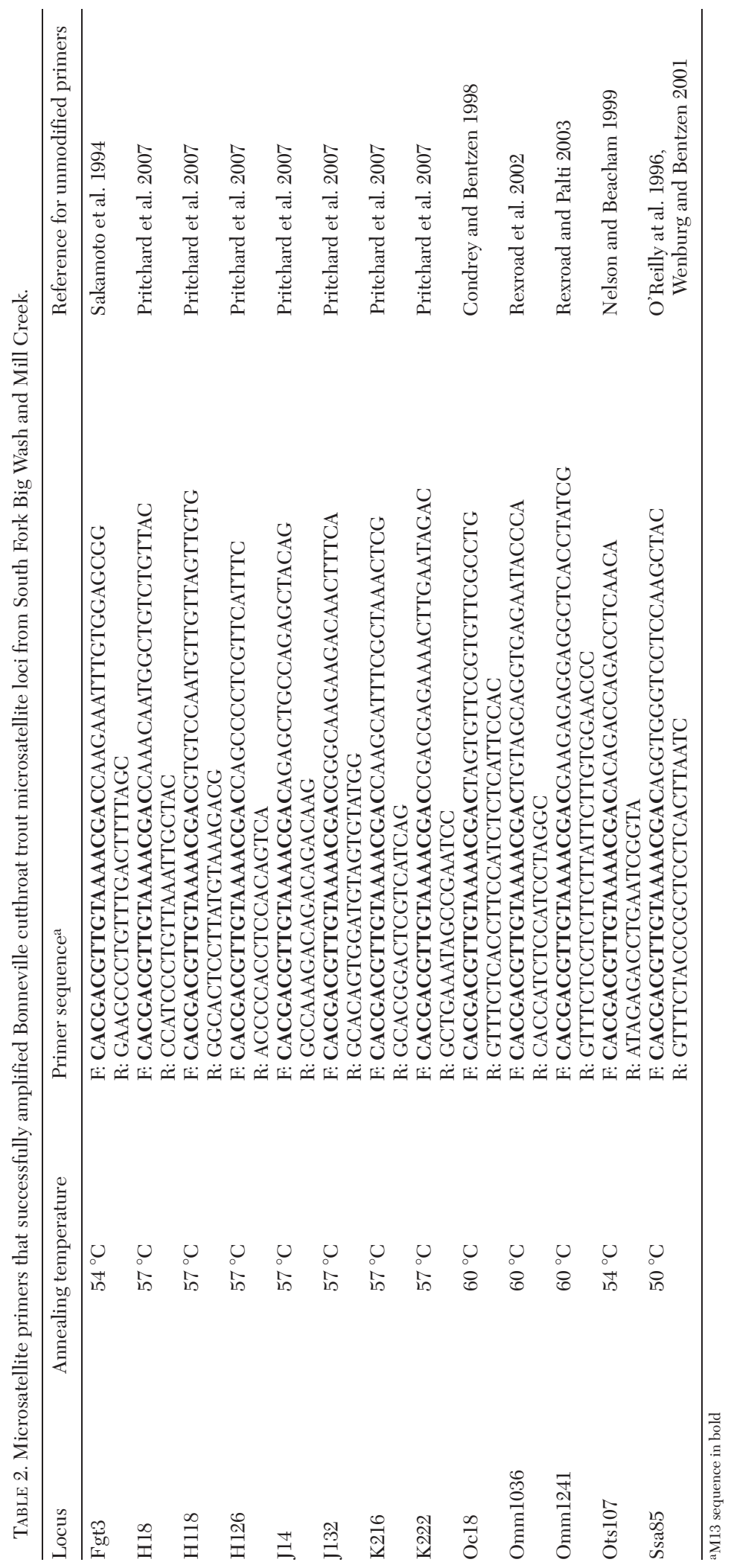




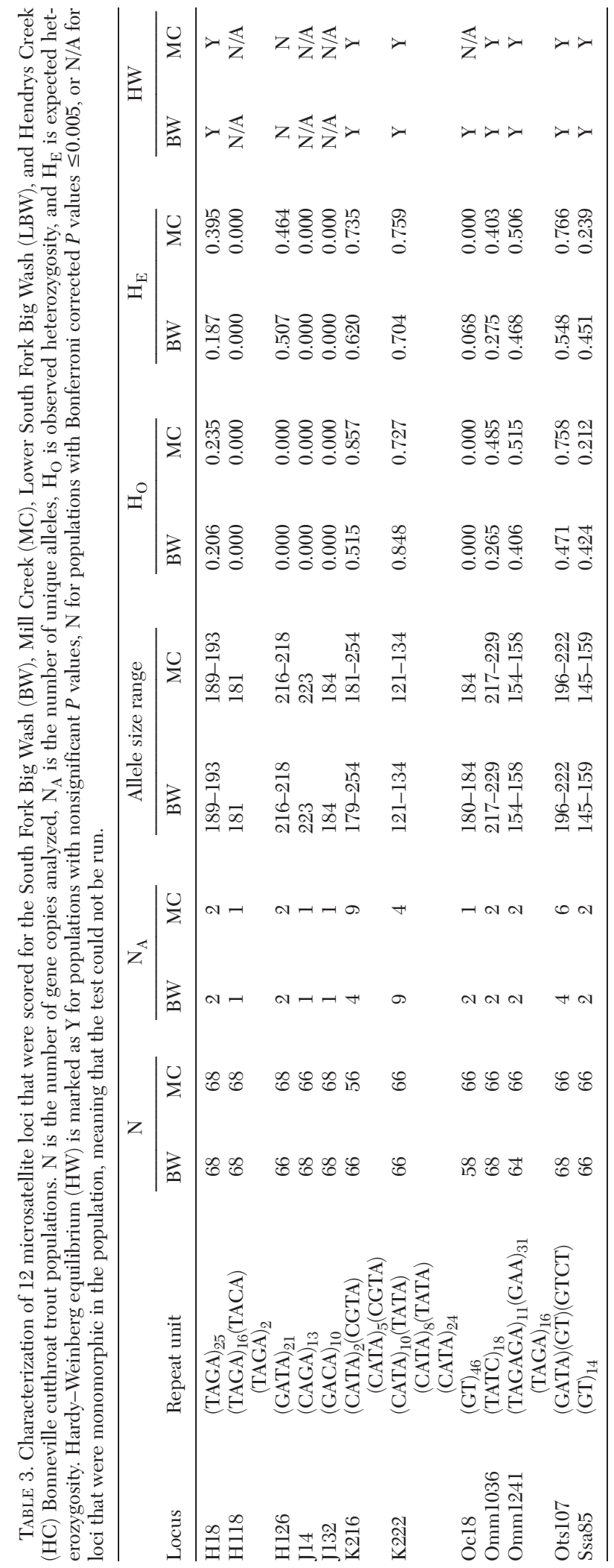




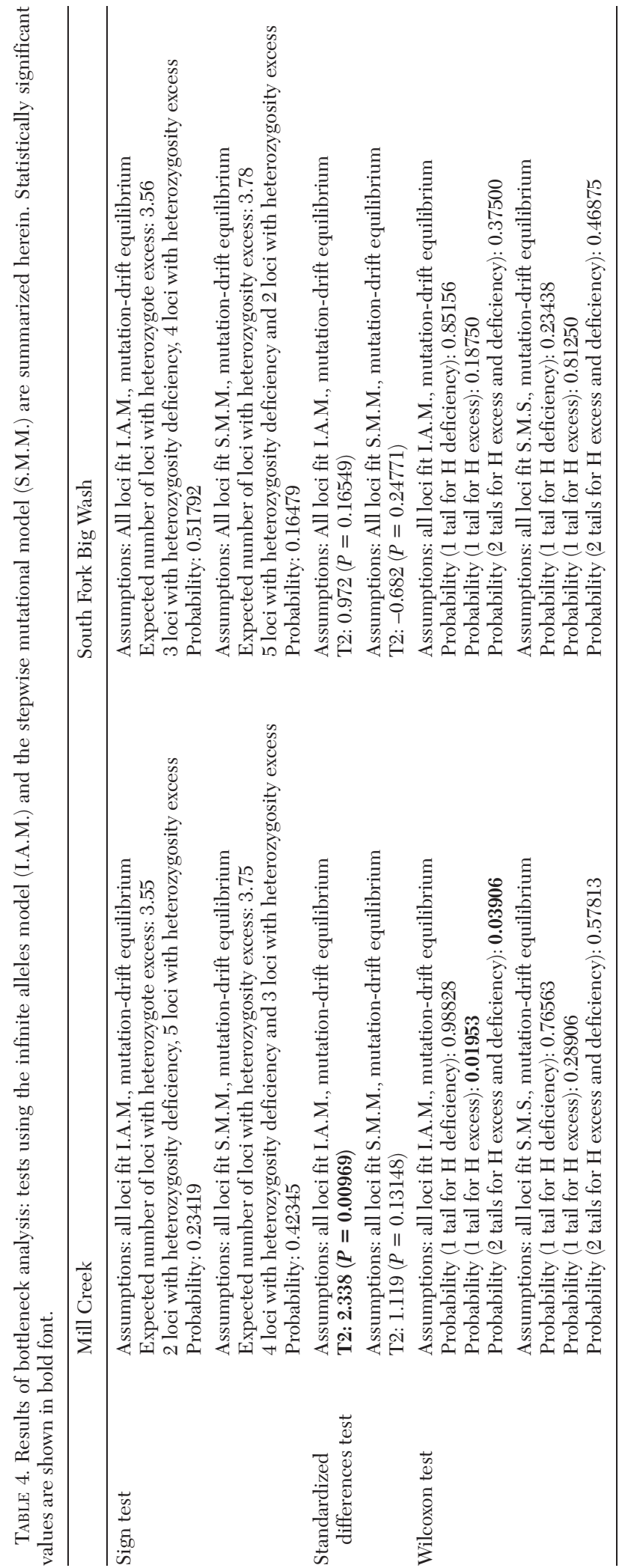


diversity were K216 in the Mill Creek population and K222 in the South Fork Big Wash population. The expected heterozygosity ranged from 0.187 to 0.766 , and the observed heterozygosity ranged from 0.040 to 0.900 (excluding the monomorphic loci for which both observed and expected heterozygosity was zero). The population pairwise $\mathrm{F}_{\mathrm{ST}}$ estimate between Mill Creek and South Fork Big Wash was $0.06727(P<0.00001)$.

\section{Population Genetic Analyses}

Tests for Hardy-Weinberg equilibrium could not be performed on monomorphic loci, but significant deviations from Hardy-Weinberg equilibrium were detected for some of the polymorphic loci (Table 3). Mill Creek had 3 loci that were not in Hardy-Weinberg equilibrium (H18, H126, K216). South Fork Big Wash also had 3 loci that were not in Hardy-Weinberg equilibrium (H126, K222, Oc18). Lower South Fork Big Wash had one locus that was not in Hardy-Weinberg equilibrium (H126). Hendrys Creek had 2 loci that were not in Hardy-Weinberg equilibrium (H126, K222).

The results of BOTTLENECK analysis revealed that the Mill Creek population shows some signs of experiencing a recent population bottleneck, whereas the South Fork Big Wash population does not. The Wilcoxon onetailed test for heterozygote excess significantly deviated from mutation-drift equilibrium under the infinite alleles model $(P=0.01953)$, and the Wilcoxon 2-tailed test for heterozygote excess and deficiency also revealed a significant departure from mutation-drift equilibrium $(P=0.03906)$ under the infinite alleles model for the Mill Creek population (Table 4). The standardized differences test also showed a significant departure from mutation-drift equilibrium $(P=0.00969)$ under the infinite alleles model (Table 4). However, this pattern did not hold for tests under the stepwise mutational model, as none of those results showed significant departure from mutationdrift equilibrium for the Mill Creek population. Hence, any signal of a population bottleneck in the Mill Creek population is weak. None of the BOTTLENECK tests resulted in significant departures from mutation-drift equilibrium in the South Fork Big Wash population under either the infinite alleles model or the stepwise mutational model (Table 4).
The results of STRUCTURE and STRUCTURE-HARVESTER revealed 4 distinct populations of Bonneville cutthroat trout. However, these 4 groups of alleles were relatively evenly distributed in the Mill Creek and South Fork Big Wash populations (Fig. 2). This observed pattern was likely driven by the monomorphic loci that occur in these 2 populations.

\section{Discussion}

The Mill Creek and South Fork Big Wash populations of Bonneville cutthroat trout have low genetic diversity among the 12 microsatellite loci that were included in this study. The 2 populations differ in the number of alleles at only 4 of the 12 loci that were successfully genotyped, and allele size ranges were identical for all but 2 of the 12 loci (Table 3). The 2 loci that did differ in allele size ranges had unique alleles in the South Fork Big Wash population that were not detected in Mill Creek. The sharing of alleles between the 2 populations is not surprising considering that Mill Creek was used as a source for the establishment of the South Fork Big Wash population. However, the significant $\mathrm{F}_{\mathrm{ST}}$ value between the Mill Creek and South Fork Big Wash populations does indicate a lack of gene flow, suggesting that some genetic differentiation has occurred since the transplant took place, possibly resulting from genetic drift. This genetic differentiation is likely manifest in subtle differences in alleles and allele frequencies. It was somewhat surprising that, of the 4 loci that exhibited differences in the number of alleles between the populations, 2 loci (K222 and Oc18) each had unique alleles in the South Fork Big Wash population that were additional to the alleles in Mill Creek, the source population for the transplant (Table 3). Typically, transplanted populations experience a founder effect, wherein individuals exhibit lower genetic diversity than those in the source population (Mayr 1942).

It is possible that some alleles in either or both populations were not sampled for this study. In part, this could be further understood if the founding population for South Fork Big Wash Creek came from a broader area in Mill Creek than was sampled for the Mill Creek microsatellite study. That does not appear to be the case, since the founding South Fork Big 


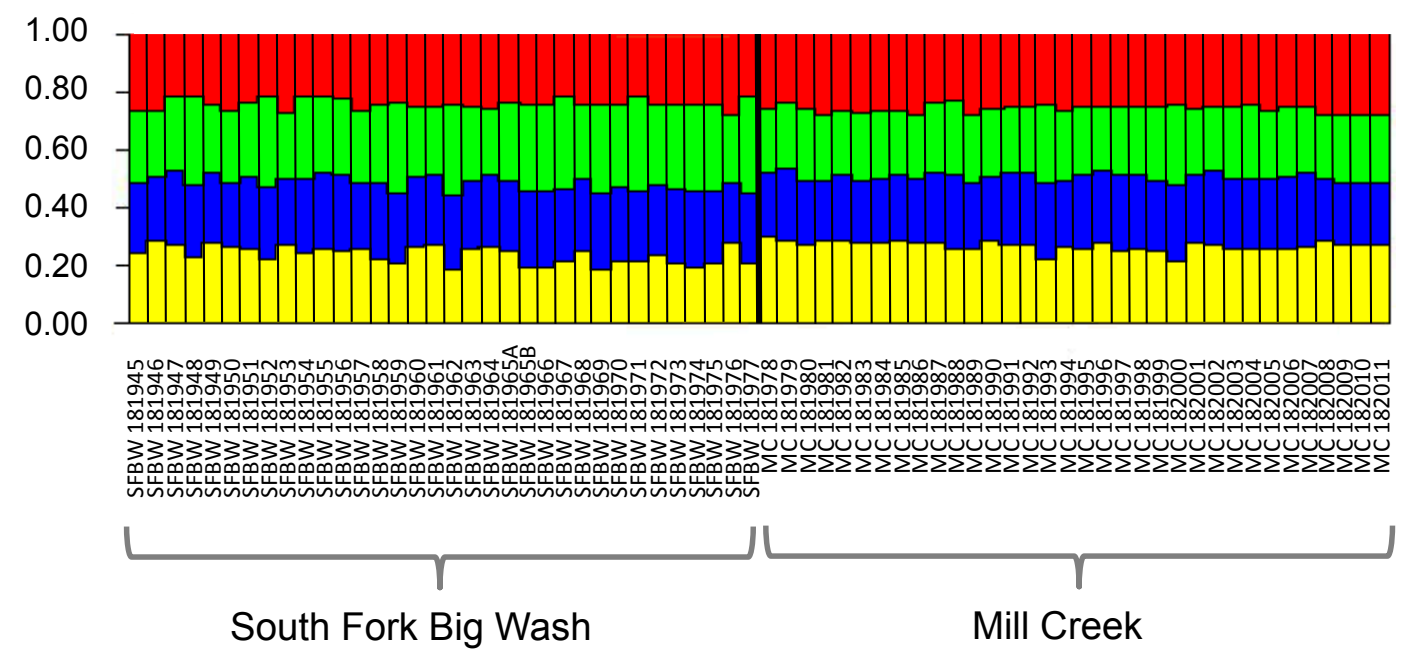

Fig. 2 Results of STRUCTURE analysis showing the frequencies of 4 groups of alleles in Mill Creek and South Fork Big Wash.

Wash population was transferred from the same location in Mill Creek that was sampled for this study (Mark Pepper, Great Basin National Park, personal communication).

Differential sampling of alleles may be associated with temporal differences in the stocking of fish into South Fork Big Wash Creek. The transfer of fish into the South Fork Big Wash Creek occurred over 2 years, one in July 2000 and the other in July of 2001. Different genotypes may have been present in the sampled area of Mill Creek during that period of time.

It is also possible that the source population in Mill Creek has undergone a population bottleneck after, or even because of, the removal of individuals to populate South Fork Big Wash. Mill Creek was the only population that exhibited a signature of a population bottleneck, although that result occurred only under the infinite alleles model, not the stepwise mutational model (Table 4). Both populations had numerous monomorphic microsatellite loci, which is typical for populations that have experienced high levels of inbreeding and/or genetic drift. These fixed loci could not be included in the BOTTLENECK analysis because their expected heterozygosity was zero, but they still indicate that the populations may have reduced genetic variation in comparison to other Bonneville cutthroat trout populations where these loci were polymorphic.

The Mill Creek and South Fork Big Wash Creek populations do show high similarity, as expected. They also show fixation at numerous loci, as expected in populations with reduced genetic variability. However, it is unclear whether inbreeding has occurred in these populations, or if so, whether the inbreeding is significant enough to raise concern about the onset of inbreeding depression. While much has been discussed regarding the problems with intense inbreeding (Wright 1921, Charlesworth and Charlesworth 1987, Mills and Smouse 1994, Hedrick and Kalinowski 2000, García-Fernández et al. 2012), relatively few cases of population loss due to such conditions have been documented in wild populations (e.g., Crnokrak and Roff 1999, Rosner 2012). The risk of loss of Bonneville cutthroat trout populations in Great Basin National Park can easily be assessed via regular population estimates in the streams, which is consistent with the idea that proper management is best handled on a case-by-case basis (Houde et al. 2011).

\section{ACKNOWLEDGMENTS}

We thank Mark Pepper (National Park Service) and Chris Crookshanks (Nevada Department of Wildlife) for providing the Bonneville cutthroat trout samples used in this study. Ed Wilcox prepared samples for sequencing once they were submitted to the BYU DNA Sequencing Center. The National Park Service provided the funding for this study. 


\section{Literature Cited}

ALLENDORF, F.W., AND R.F. LEARY. 1988. Conservation and distribution of genetic variation in a polytypic species, the cutthroat trout. Conservation Biology 2:170-184.

Amos, W., AND A. BALMFond. 2001. When does conservation genetics matter? Heredity 87:257-265.

BeHnKe, R.J. 2002. Trout and salmon of North America. The Free Press, New York, NY. 359 pp.

Blacket, M.J., C. Robin, R.T. Good, S.F. Lee, and A.D. MiLLER. 2012. Universal primers for fluorescent labeling of PCR fragments - an efficient and costeffective approach to genotyping by fluorescence. Molecular Ecology Resources 12:456-463.

Cegelski, C.C., M.R. Campbell, K.A. Meyer, and M.S. PowELL. 2006. Multiscale genetic structure of Yellowstone cutthroat trout in the Upper Snake River Basin. Transactions of the American Fisheries Society 135:711-726.

Charlesworth, D., and B. Charlesworth. 1987. Inbreeding depression and its evolutionary consequences. Annual Review of Ecology and Systematics $18: 237-268$

Charlesworth, D., and J.H. Willis. 2009. The genetics of inbreeding depression. Nature Reviews Genetics 10:783-796.

Condrey, M.J., And P. Bentzen. 1998. Characterization of coastal cutthroat trout (Oncorhynchus clarki clarki) microsatellites and their conservation in other salmonids. Molecular Ecology 7:787-789.

Cornuet, J.M., and G. Luikart. 1996. Description and power analysis of two tests for detecting recent population bottlenecks from allele frequency data. Genetics 144:2001-2014

Crnokrak, P., and D.A. Roff. 1999. Inbreeding depression in the wild. Heredity 83:260-270.

Dennenmoser, S., A.W. Nolte, S.M. Vamosi, and S.M. Rogers. 2013. Conservation genetics of prickly sculpin (Cottus asper) at the periphery of its distribution range in Peace River, Canada. Conservation Genetics 14:735-739.

EARL, D.A., AND B.M. vONHoLDT. 2012. Structure Harvester: a website and program for visualizing STRUCTURE output and implementing the Evanno method. Conservation Genetics Resources 4:359-361.

Ellstrand, N.C., and D.R. Elam. 1993. Population genetic consequences of small population size: implications for plant conservation. Annual Review of Ecology and Systematics 24:217-242.

ExCOFFIER, L., AND H.E.L. LISCHER. 2010. Arlequin suite version 3.5: a new series of programs to perform population genetics analyses under Linux and Windows. Molecular Ecology Resources 10:564-567.

García-Fernández, A., J.M. Iriondo, and A. Escudero. 2012. Inbreeding at the edge: does inbreeding depression increase under more stressful conditions? Oikos 121:1435-1445.

Hanna, N., D. Brown, L.J. Avila, J.W. Sites Jr., M. Morando, AND F.M. Fontanella. 2012. Characterization of 10 polymorphic microsatellite loci in the South American lizard Liolaemus fizingerii with cross-amplification in L. chehuachekenk. Conservation Genetics Resources 4:105-107.

HEDRICK, P.W., AND S.T. KALINOWSKI. 2000. Inbreeding depression in conservation biology. Annual Review of Ecology and Systematics 31:139-162.
Houde, A.L.S., D.J. Fraser, P. O'Reilly, and J.A. Hutchings. 2011. Relative risks of inbreeding and outbreeding depression in the wild in endangered salmon. Evolutionary Applications 4:634-647.

Houston, D.D., D.B. Elzinga, P.J. Maughan, S.M. Smith, J.S.K. KaUwe, R.P. Evans, R.B. Stinger, and D.K. ShiozaWa. 2012. Single nucleotide polymorphism discovery in cutthroat trout subspecies using genome reduction, barcoding, and 454 pyrosequencing. BMC Genomics 13:724.

KINCAID, H.L. 1976. Effects of inbreeding on rainbow trout populations. Transactions of the American Fisheries Society 105:273-280.

LACY, R.C. 2000. Considering threats to the viability of small populations using individual-based models. Ecological Bulletins 48:39-51.

Leary, R.F., F.W. Allendorf, and K.L. Knudson. 1985. Developmental instability as an indicator of reduced genetic variation in hatchery trout. Transactions of the American Fisheries Society 114:230-235.

LesicA, P., AND F.W. Allendorf. 1995. When are peripheral populations valuable for conservation? Conservation Biology 9:753-760.

MAYR, E. 1942. Systematics and the origin of species. Columbia University Press, New York, NY.

Metcalf, J.L., S.L. Stowell, C.M. Kennedy, K.B. Rogers, D. McDonald, J. Epp, K. Keepers, A. Cooper, J.J. Austin, AND A.P. MarTin. 2012. Historical stocking data and 19th century DNA reveal human-induced changes to native diversity and distribution of cutthroat trout. Molecular Ecology 21:5194-5207.

MiLls, L.S., AND P.E. Smouse. 1994. Demographic consequences of inbreeding in remnant populations. American Naturalist 144:412-431.

Moritz, C. 1999. Conservation units and translocations: strategies for conserving evolutionary processes. Hereditas 130:217-228.

Moritz, C. 2002. Strategies to protect biological diversity and the evolutionary processes that sustain it. Systematic Biology 51(2):238-254.

Nelson, R.J., and T.D. BEACHAM. 1999. Isolation and cross species amplification of microsatellite loci useful for study of Pacific salmon. Animal Genetics 30:228-229.

Newman, D., AND D. Pilson. 1997. Increased probability of extinction due to decreased genetic effective population size: experimental populations of Clarkia pulchella. Evolution 51:354-362.

Nielsen, J.L., And G.K. Sage. 2002. Population genetic structure in Lahontan cutthroat trout. Transactions of the American Fisheries Society 131:376-388.

o'Brien, S.J., M.E. Roelke, L. Marker, A. Newman, C.A. Winkler, D. Meltzer, L. Colly, J.F. EverMANN, M. BUSH, AND D.E. WILDT. 1985. Genetic basis for species vulnerability in the cheetah. Science 227:1428-1434.

O’Reilly, P.T., L.C. Hamilton, S.K. McConnell, and J.M. WRight. 1996. Rapid analysis of genetic variation in Atlantic salmon (Salmo salar) by PCR multiplexing of dinucleotide and tetranucleotide microsatellites. Canadian Journal of Fisheries and Aquatic Science 53:2292-2298.

Peterman, W.E., S.M. Feist, R.D. Semlitsch, and L.S. EGGERT. 2013. Conservation and management of peripheral populations: spatial and temporal influences on the genetic structure of wood frog (Rana sylvatica) populations. Biological Conservation 158:351-358. 
Pritchard, J.K., M. Stephens, and P. Donnelly. 2000. Inference of population structure using multilocus genotype data. Genetics 155:945-959.

Pritchard, V.L., K. Jones, J.L. Metcalf, A.P. Martin, P. Wilkinson, AND D.E. Cowley. 2007. Characterization of tetranucleotide microsatellites for Rio Grande cutthroat trout,and rainbow trout and their cross-amplification in other cutthroat trout subspecies. Molecular Ecology Notes 7:594-596.

Raymond, M., AND F. Rousset. 1995. GENEPOP (version 1.2): population genetics software for exact tests and ecumenicism. Journal of Heredity 86:248-249.

Reed, D.H., and R. Frankham. 2003. Correlation between fitness and genetic diversity. Conservation Biology 17:230-237.

Rexroad, C.E., III, and Y. PaLti. 2003. Development of ninety-seven polymorphic microsatellite markers for rainbow trout. Transactions of the American Fisheries Society 132:1214-1221.

Rexroad, C.E., III, R.L. Coleman, A.L. Gustafson, W.K. Hershberger, and J. Killefer. 2002. Development of rainbow trout microsatellite markers from repeat enriched libraries. Marine Biotechnology 4:12-16.

Robinson, M.L., V.S. Kirchoff, AND M.M. PEACOCK. 2009. Characterization of 13 microsatellites for Lahontan cutthroat trout (Oncorhynchus clarki henshawi) and cross-amplification in six other salmonids. Molecular Ecology Resources 9:134-136.

Rosner, H. 2012. Attack of the mutant pupfish. Wired Science. [Accessed 14 February 2014]. http://www.wired .com/wiredscience/2012/11/mf-mutant-pupfish/all/

Rousset, F. 2008. Genepop'007: a complete reimplementation of the Genepop software for Windows and Linux. Molecular Ecology Resources 8:103-106.

Sakamoto, T., N. OKamoto, Y. Ikeda, Y. NaKamura, and T. SATO. 1994. Dinucleotide-repeat polymorphism in DNA of rainbow trout and its application in fisheries science. Journal of Fish Biology 44:1093-1096.

Schuelke, M. 2000. An economic method for the fluorescent labeling of PCR fragments. Nature Biotechnology 18:233-234.

Spielman, D., B.W. Brook, and R. Frankham. 2004. Most species are not driven to extinction before genetic factors impact them. Proceedings of the National Academy of Science USA 101:15261-15264.

Su, G.S., L.E. Liliedahl, and G.A.E. GaLl. 1996. Effects of inbreeding on growth and reproduction traits in rainbow trout (Oncorhynchus mykiss). Aquaculture 142:139-148.
Taylor, E.B., M.D. Samford, J.S. BaXter. 2003. Population subdivision in westslope cutthroat trout (Oncorhynchus clarki lewisi) at the northern periphery of its range: evolutionary inferences and conservation implications. Molecular Ecology 12:2609-2622.

Trotter, P. 2008. Cutthroat: native trout of the west. 2nd edition. University of California Press, Berkeley, CA. $560 \mathrm{pp}$.

Van Oosterhout, C., W.F. Hutchinson, D.P.M. Wills, AND P. SHIPLEy. 2004. Micro-Checker: software for identifying and correcting genotyping errors in microsatellite data. Molecular Ecology Notes 4:535-538.

Vu, N.V., ANd S.T. KaLinowski. 2009. Twelve tetranucleotide microsatellite loci for westslope cutthroat trout Oncorhynchus clarki lewisi (Salmonidae). Conservation Genetics Resources 1:249-251.

Wang, S.Z., J.J. HaRd, AND F. UTTER. 2002. Genetic variation and fitness in salmonids. Conservation Genetics 3:321-333.

WAPLES, R.S. 1994. Genetic considerations in recovery efforts for Pacific salmon. Conservation Biology 8: 884-886.

Wenburg, J.K., and P. Bentzen. 2001. Genetic and behavioral evidence for restricted gene flow among coastal cutthroat trout populations. Transactions of the American Fisheries Society 130:1049-1069.

Wenburg, J.K., P. Bentzen, and C.J. Foote. 1998. Microsatellite analysis of genetic population structure in an endangered salmonid: the coastal cutthroat trout (Oncorhynchus clarki clarki). Molecular Ecology 7:733-749.

WRIGHT, S. 1921. Systems of mating II: the effects of inbreeding on the genetic composition of a population. Genetics 6:124-143.

YaU, M.M., AND E.B. TAYlor. 2013. Environmental and anthropogenic correlates of hybridization between westslope cutthroat trout (Oncorhynchus clarkii lewisi) and introduced rainbow trout (O. mykiss). Conservation Genetics 14:885-900.

Young, S.F., J.G. McLellan, and J.B. Shaklee. 2004. Genetic integrity and microgeographic population structure of westslope cutthroat trout, Oncorhynchus clarki lewisi, in the Pend Oreille Basin in Washington. Environmental Biology of Fishes 69:127-142.

Received 17 March 2014 Accepted 20 March 2015 